\title{
Reduction in Peripheral Lymphocytes and Thymus Atrophy Induced by Organotin Compounds In Vivo
}

\author{
Shunji UENO ${ }^{1) *}$, Takashige KASHIMOTO ${ }^{1)}$, Nobuyuki SUSA ${ }^{1)}$, Tomohito ASAI ${ }^{1}$, Souta KAWAGUCHI ${ }^{1)}$, Shino \\ TAKEDA-HOMMA ${ }^{2)}$, Yasuko TERADA ${ }^{3)}$ and Masayasu SUGIYAMA ${ }^{4)}$ \\ ${ }^{1)}$ Laboratory of Veterinary Public Health, School of Veterinary Medicine, Kitasato University, Higashi 23-35-1, Towada, Aomori 034-8628, \\ ${ }^{2)}$ National Institute of Radiation Sciences, 4-9-1, Anagawa, Inage-ku, Chiba 263-8555, ${ }^{3)}$ Japan Synchrotoron Radiation Research \\ Institute, Mikazuki, Hyogo 679-5198 and ${ }^{4)}$ Sugiyama Pharmacy, 1135-1 Shimotama, Hagi, Yamaguchi 759-3112, Japan
}

(Received 14 January 2009/Accepted 30 March 2009)

ABSTRACT. To clarify the involvement of apoptosis in the immunotoxicity of organotin compounds, we examined the induction of apop-
tosis in the peripheral lymphocytes and thymus of mice treated with triphenyltin (TPT), tributyltin (TBT) or dexamethasone (Dex). Appli-
cation of TPT or TBT and Dex resulted in a transient reduction in peripheral lymphocytes at 3 to $6 \mathrm{hr}$, and thymus atrophy was observed
at 6 and $24 \mathrm{hr}$ after administration. Lymphocyte subpopulation analysis showed that TPT and TBT induced a greater reduction in B
cells than in T cells. The maximum levels of organotin in the blood were about $450 \mathrm{ng} \mathrm{TPT} / \mathrm{ml}$ in the TPT-treated mice, and $170 \mathrm{ng}$
$\mathrm{TBT} / \mathrm{m} l \mathrm{in}$ the TBT-treated mice. When the isolated peripheral lymphocytes were incubated with the organotins at $500 \mathrm{ng} / \mathrm{ml}, \mathrm{TPT}$ and
$\mathrm{TBT} \mathrm{induced}$ necrosis in over $70 \%$ of cells, while both organotins caused lower percentages of apoptosis as well as necrosis after $3 \mathrm{hr}$
at $100 \mathrm{ng} / \mathrm{m} l$. In the thymus, although in vivo treatment of mice with Dex caused apoptosis, neither apoptotic nor necrotic thymocytes
were observed in the TPT- and TBT-treated mice, indicating that the thymus atrophy might be caused by the antiproliferative effects of
these organotin compounds. Thus, our results did not support the idea that apoptosis played a decisive part in the immunotoxicity of
the organotin compounds in vivo. KEY WORDS: organotin compounds, peripheral lymphocytes, thymus atrophy.

The toxicity of organotin compounds has attracted special interest because of their expanding utilization and pollution resulting from organotin compounds in the form of plastic stabilizers, catalytic agents, industrial agricultural biocides, anti-fouling paints and pesticides [10]. Although the production and use of these organotin compounds are regulated, environmental contamination still persists [11-13]. Recently, the areas reporting organotin compounds as environmental pollutants are shifting from advanced countries to the developing countries [25]. Human exposure to organotin compounds may come from consumption of organotincontaminated meat and fish products because food chain accumulation and bioconcentration have been demonstrated in some marine species [3].

Organotin compounds are reported to cause serious health problems, particularly endocrine disruption in some marine species [9] as well as in experimental animals [8], and are suspected to have immunotoxic effects in mammals $[3,29]$. Among the toxic effects of organotin compounds, immunotoxicity is particularly notable in many species of mammals [18]. Triphenyltin (TPT), tributyltin (TBT) and dibutyltin (DBT) have been shown to induce thymus atrophy $[22,23,29]$ in vivo, and depletion of cortical thymocytes has been observed upon treatment with these compounds. Previous studies have shown that relatively low doses of DBT [19] and TBT [6] selectively inhibit the

\footnotetext{
* Correspondence to: Ueno, S., Laboratory of Veterinary Public Health, School of Veterinary Medicine, Kitasato University, Higashi 23-35-1, Towada, Aomori 034-8628, Japan.

e-mail: ueno@vmas.kitasato-u.ac.jp
}

proliferation of immature $\mathrm{CD} 4(-) \mathrm{CD} 8(+) \mathrm{CD} 3(-/$ low $)$ and CD4(+)CD8(+)CD3(-/low) thymocytes without signs of apoptotic cell death. However, various studies have shown that organotins at high doses induce apoptosis in rat thymocytes in vitro and in vivo $[2,5,7,15,17,20]$ and suggest that exposure to TPT and TBT actually triggers apoptosis, rather than being directly cytotoxic. Moreover, Stridh et al. reported that TBT can induce caspase activation and apoptosis in human peripheral lymphocytes in vitro and suggested that TBT-induced deletion of peripheral lymphocytes is likely a component in the overall risk for immunotoxic responses in exposed humans [24]. Therefore, the participation of apoptosis induced by these organotin compounds has been a major theme in toxicological evaluation of organotins, although the relative contribution of apoptosis to the reduction of peripheral lymphocytes and thymus atrophy in whole body in vivo experiments remains unclear.

In the present study, in order to evaluate the contribution of apoptosis or necrosis in the reductions of peripheral lymphocytes and thymus atrophy induced by organotin compounds such as TPT and TBT in mice, we analyzed apoptotic cells in peripheral lymphocytes or thymocytes in vitro and in vivo by flow cytometry and the distribution and metabolism of the organotin compounds in vivo.

\section{MATERIALS AND METHODS}

Chemicals: Triphenyltin chloride (TPT) and diphenyltin dichloride (DPT) were obtained from Kanto Chemical Co., Inc., (Tokyo, Japan). Tri-n-butyltin chloride (TBT) and 
dibutyltin dichloride (DBT) were purchased from Tokyo Kasei Kogyo Co., Ltd. (Tokyo, Japan). Dexamethasone (Dex) was obtained from Wako Pure Chemical Industries Ltd. (Osaka, Japan) as the positive control for induction of apoptosis. All chemicals used were of the highest quality commercially available.

Animals: The experiments were performed in accordance with Japanese legislation concerning the protection of animals and the 'Guide for the Care and Use of Laboratory Animals' (NIH publication no. 86-23, revised 1985) after approval by the Committee of Animal Experimentation at Kitasato University School of Veterinary Medicine. ICR male mice 8 weeks of age were purchased from SLC Inc. (Hamamatsu, Japan). The mice were fed a standard cubed diet (MF, Oriental Yeast Co., Ltd., Tokyo, Japan), maintained on distilled water ad libitum and exposed to a 12-hr light (7:00 AM to 7:00 PM) and 12-hr dark (7:00 PM to 7:00 AM) cycle. The ambient temperature during the study was maintained at about $21^{\circ} \mathrm{C}$.

Treatment: TPT or TBT was dissolved in corn oil (Sigma Aldrich Co., St. Louis, MO, U.S.A.) and administered orally $(10 \mathrm{ml} / \mathrm{kg}$ for mice). The dosage of the organotin compounds in our experiments was $180 \mu \mathrm{mol} / \mathrm{kg}$, respectively (TPT, $69 \mathrm{mg} / \mathrm{kg}$; TBT, $63 \mathrm{mg} / \mathrm{kg}$ ). These dosages are equivalent to the dosage $(196 \mu \mathrm{mol} / \mathrm{kg})$ of TBT reported to induce apoptosis in vivo [20]. We also injected Dex as an apoptosis inducer at a dosage of $3 \mathrm{mg} / \mathrm{kg}$ intraperitoneally.

Extraction and measurement of organotin compounds from samples: The phenyltin or butyltin compounds were extracted from the blood or thymus and purified by the method of Suzuki et al. [26]. The levels of each organotin compound in the samples were determined by the method of Suzuki et al. [26], using an HP Model 5890 Series II gas chromatograph (Hewlett-Packard, Avondale, PA, U.S.A.) equipped with a split/splitless injection port connected to an HP Model 5921A atomic emission detector equipped with a turbo makeup gas valve.

Total and differential leukocyte counts: Blood samples were collected via heart puncture under ether anesthesia into tubes containing EDTA at 3, 6, 24 and $48 \mathrm{hr}$ after treatment. Total peripheral blood leukocyte counts were abtained by staining with Turk's solution and counting using a hemocytometer. Differential cell counts were performed on blood smears stained with Wright-Giemsa dyes.

Analysis of lymphocyte subpopulation by flow cytometry: Peripheral lymphocytes were isolated from the blood using Lymphoprep (Nycomed, Oslo, Norway). Single-cell suspensions of lymphocytes, prepared as described above, were washed twice in cold Hanks' balanced salt solution (HBSS). After washing, $1 \times 10^{6}$ cells were resuspended in $50 \mu l$ of PBS with $1 \%$ bovine serum albumin (BSA) and $0.01 \%$ sodium azide. Anti-mouse CD4-PE, anti-mouse CD8FITC, anti-mouse CD3-FITC or anti-mouse CD45R (B220)-PE (Immunotech, Marseille, France) were added to the cell suspensions at appropriate dilutions, and the cell suspensions were then incubated for $30 \mathrm{~min}$ at $4^{\circ} \mathrm{C}$ to detect the respective cell surface markers. The cell suspensions were washed twice with PBS containing 1\% BSA and $0.01 \%$ sodium azide, and then the numbers of stained cells were determined by counting about 10,000 cells on a fluorescence-activated cell sorter (FACS 440, Becton Dickinson, Bedford, U.S.A.).

Analysis of apoptotic lymphocytes by flow cytometry: We also observed the ratio of necrotic or apoptotic cells in isolated peripheral lymphocytes treated with Dex or organotin compounds. Isolated peripheral lymphocytes $\left(1.0 \times 10^{6}\right.$ cells $/ \mathrm{m} l$ ) suspended in RPMI-1640 medium were incubated with Dex or organotin compounds at $37^{\circ} \mathrm{C}$ for 1 or $3 \mathrm{hr}$. After incubation, the lymphocytes were stained with FITCAnnexin V and propidium iodide (PI) using an Annexin-VFLUOS Staining Kit (Roche Diagnostics GmbH, Penzberg, Germany) and analyzed by a fluorescence-activated cell sorter (FACS 440, Becton Dickinson, Bedford, U.S.A.). The flow cytometry test can discriminate intact cells (Annexin-/PI-), early apoptotic cells (Annexin+/PI-), late apoptotic cells or necrotic cells (Annexin+/PI + ) and necrotic cells (Annexin-/PI+).

Analysis of DNA fragmentation: DNA fragmentation was analyzed as described previously with some modifications $[14,27]$. Briefly, thymus tissues from the mice were gently glass-ground to dissociate the cells, suspended in cold HBSS and then gently passed through a stainless steel mesh to obtain single-cell suspensions of thymocytes. Cells $(5 \times$ $\left.10^{6}\right)$ in HBSS were centrifuged, and the resulting pellet was suspended for $10 \mathrm{~min}$ at $4^{\circ} \mathrm{C}$ in lysis buffer $(10 \mathrm{mM}$ Tris$\mathrm{HCl}$, pH 7.4, 10 mM EDTA, 0.5\% Triton X-100). Samples were then centrifuged at $14,000 \times \mathrm{g}$ for $5 \mathrm{~min}$, and the supernatants containing the fragmented DNA were digested with $200 \mu \mathrm{g} / \mathrm{m} l$ of RNase (Sigma Aldrich, St. Louis, MO, U.S.A.) for $1 \mathrm{hr}$ at $37^{\circ} \mathrm{C}$. The samples were then treated with $200 \mu \mathrm{g} / \mathrm{m} l$ Proteinase K (Merck, Darmstadt, Germany) for $30 \mathrm{~min}$ at $50^{\circ} \mathrm{C}$. The supernatants were precipitated overnight using isopropyl alcohol. DNA fragments were separated on $2.0 \%$ agarose gels, visualized with ethidium bromide and photographed.

Statistical analysis: The differences between the averages of 4 treated animals and the untreated control animals were compared using Dunnett's test after one-way ANOVA, and a $p$ value of less than 0.05 was considered statistically significant. Data from studies with only two groups were analyzed by the Student's $t$ test for equal variance or Welch's $t$ test for unequal variance after Bartlett's test.

\section{RESULTS}

Concentration of TPT or TBT and their metabolites in the blood of mice: First, we analyzed the concentrations of organotins including their main metabolites in the blood at 0.5 to $6 \mathrm{hr}$ after oral administration. In the TPT-treated mice, the levels of TPT in the blood reached a maximum level of 445 $n \mathrm{~g} / \mathrm{m} l$ at $1 \mathrm{hr}$ after administration, and diphenyltin (DPT), a metabolite of TPT, was also detected in the same samples (Table 1). On the other hand, the levels of TBT in the blood were about $100 \mathrm{ng} / \mathrm{m} l$ at $3 \mathrm{hr}$ after administration, at which 
Table 1. The concentrations of organotin compounds in the blood of mice administered TPT or TBT

\begin{tabular}{clcc}
\hline & & TPT $(n \mathrm{~g} / \mathrm{m} l$ or $\mathrm{g})$ & DPT $(n \mathrm{~g} / \mathrm{m} l$ or $\mathrm{g})$ \\
\hline TPT & $0.5 \mathrm{hr}$ & $129.5 \pm 98.0$ & $\mathrm{ND}$ \\
& $1 \mathrm{hr}$ & $445.5 \pm 148.2$ & $256.1 \pm 46.1$ \\
& $3 \mathrm{hr}$ & $299.0 \pm 189.3$ & $2.1 \pm 5.1$ \\
& $6 \mathrm{hr}$ & $388.9 \pm 163.0$ & $\mathrm{ND}$ \\
\hline TBT & $0.5 \mathrm{hr}$ & $85.1 \pm 38.8$ & $64.4 \pm 4.5$ \\
& $1 \mathrm{hr}$ & $83.8 \pm 15.9$ & $49.1 \pm 21.3$ \\
& $3 \mathrm{hr}$ & $104.4 \pm 32.5$ & $32.6 \pm 7.8$ \\
& $6 \mathrm{hr}$ & $174.2 \pm 40.4$ & $56.5 \pm 42.9$ \\
\hline
\end{tabular}

TPT or TBT was adminsitered orally $(180 \mu \mathrm{mol} / \mathrm{kg})$, and the organotin compounds in the blood were analyzed by the GC-MS method. Values are indicated as means \pm SD $(n=4)$. ND: Not detected.

point a transient reduction in peripheral lymphocytes could be observed.

Effects of TPT or TBT on peripheral lymphocytes: Figure 1 shows the effects of TPT, TBT and Dex administration on the number of peripheral lymphocytes in mice. Significant transient decreases in peripheral lymphocytes were observed at $3 \mathrm{hr}$ to $6 \mathrm{hr}$ in the Dex-, TPT- and TBT-treated mice. In the TBT-treated mice, this transient decrease was smaller than that in the TPT-treated mice, and an increase induced by dehydration was observed after $48 \mathrm{hr}$. As shown in Fig. 2, flow cytometric analysis of the reduction rates of $\mathrm{T}$-cells and B-cells in the peripheral lymphocytes of the mice treated with the TPT or TBT showed that the numbers of B-cells were dramatically reduced to about $30 \%$ and $24 \%$ of the control while those of T-cells were about $55 \%$ and $56 \%$ of the control after TPT or TBT treatment at $6 \mathrm{hr}$, respectively. It should be noted that the organotins induced greater reductions in B-cells than in T-cells.

Effects of exposure to TPT or TBT at the actual levels found in blood on isolated lymphocytes in vitro: Next, we tried to detect apoptotic lymphocytes in the blood of treated mice in vivo. Although the typical apoptotic thymocytes and DNA laddering were detected in the thymus from the Dex-treated mice, we could not detect the typical DNA laddering, annexin V (+) lymphocytes or PI $(+)$ lymphocytes in any of the Dex-, TPT- or TBT-treated mice in the peripheral lymphocytes at 0.5 to $24 \mathrm{hr}$ after administration (data not shown). Therefore, we observed the in vitro effects of these chemicals on isolated peripheral lymphocytes using the actual concentrations of organotins observed in vivo.

Figures 3 and 4 present the effects of the Dex $\left(10^{-6} \mathrm{M}=\right.$ $392 n \mathrm{~g} / \mathrm{m} l)$, TPT (100 or $500 n \mathrm{~g} / \mathrm{m} l)$ and TBT (100 or 500 $n \mathrm{~g} / \mathrm{m} l)$ treatments on the isolated peripheral lymphocytes prepared from normal mice. The higher concentration of TPT $(500 n \mathrm{~g} / \mathrm{m} l)$ is equivalent to the maximum TPT concentration in the blood of the TPT-treated mice, and the lower concentration of TBT $(100 \mathrm{ng} / \mathrm{m} l)$ is equivalent to the maximum TBT levels in the blood of the TBT-treated mice (Table 1). Dex treatment resulted in an increase in the annexin $\mathrm{V}(+)$ lymphocytes after $3 \mathrm{hr}$ of incubation, indicating induction of apoptosis. The extreme increase in annexin

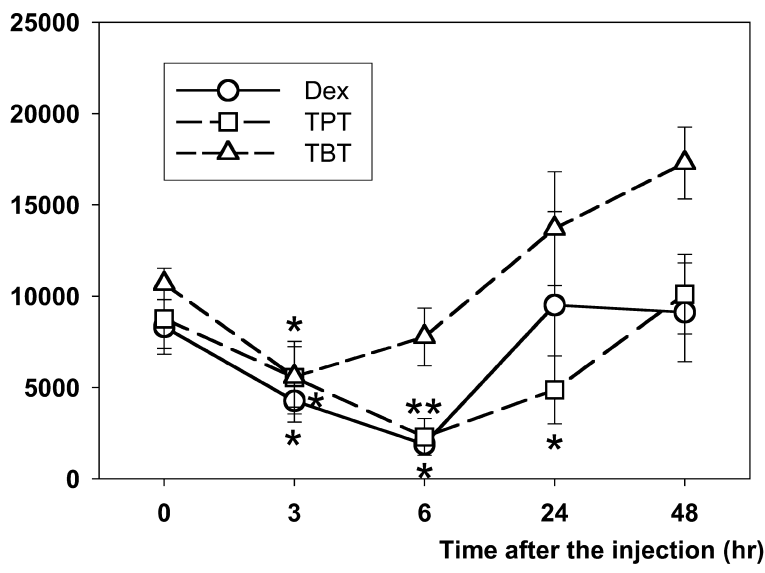

Fig. 1. Effects of organotin compounds on the peripheral lymphocyte counts in mice. The organotin compounds were administered orally $(180 \mu \mathrm{mol} / \mathrm{kg})$, while dexamethasone $(3 \mathrm{mg} / \mathrm{kg})$ was given intraperitoneally. Values are indicated as means \pm SD $(\mathrm{n}=4), *, * *$ : Significantly different from the values before administration $(\mathrm{p}<0.05$ or 0.01$)$.

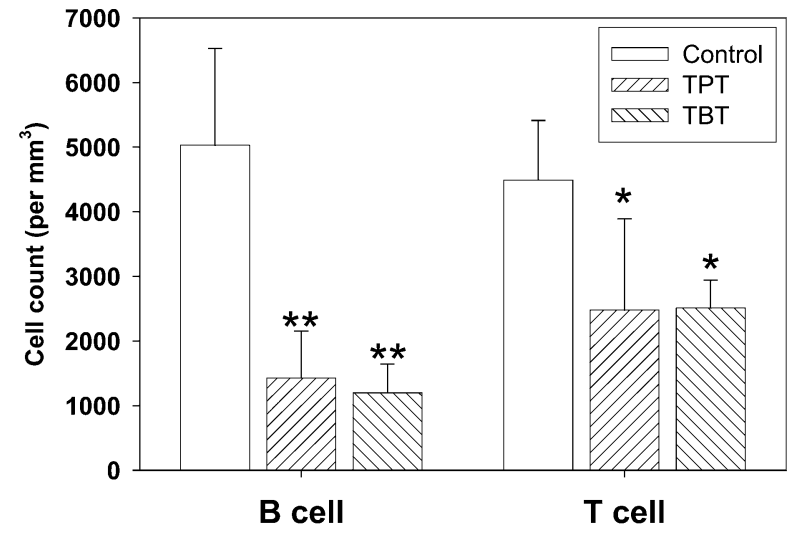

Fig. 2. Effects of organotin compounds on the peripheral subpopulations in mice at $6 \mathrm{hr}$ after administration. The mice were administered the organotin compound $(180 \mu \mathrm{mol} / \mathrm{kg})$ orally, and the cell counts of each subset were calculated from the results of FACS analysis. Values are indicated as means \pm SD $(n=4), *$, **: Significantly different from the values before administration $(\mathrm{p}<0.05$ or 0.01$)$.

V (-) PI (+) lymphocytes resulting from the higher concentrations of TPT and TBT $(500 \mathrm{ng} / \mathrm{m} l)$ indicates that the treatments with higher concentrations of TPT or TBT could induce necrosis in the isolated lymphocytes at $1 \mathrm{hr}$ of incubation. On the other hand, treatment with the lower concentration of TBT $(100 \mathrm{ng} / \mathrm{ml})$ resulted in an increase of both annexin V (+) PI (-) cells and annexin V (-) PI (+) cells, indicating that the treatment with the lower concentration of TBT could induce apoptosis and necrosis in the peripheral lymphocytes. However, treatment with the lower concentration of TPT or DBT induced only apoptosis at $3 \mathrm{hr}$ of incubation.

Effects of TPT or TBT on the thymus in vivo: With respect 


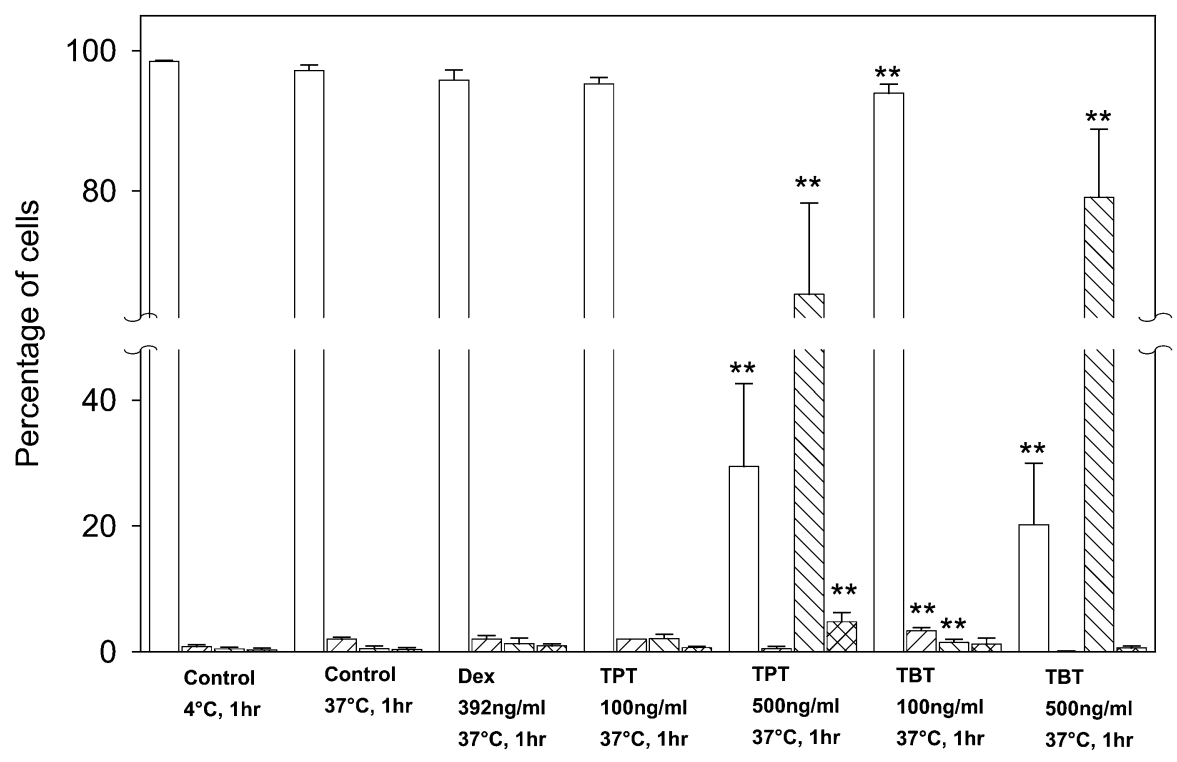

Fig. 3. The effects of organotin treatments on lymphocytes prepared from normal mouse peripheral blood in vitro (1). The lymphocytes were incubated with the organotin compounds $(392 \mathrm{ng} / \mathrm{m} l$ for Dex; 100 or $500 \mathrm{ng} / \mathrm{ml}$ for TPT and TBT) in RPMI- 1640 medium at $37^{\circ} \mathrm{C}$ for $1 \mathrm{hr}$, and then the apoptotic or necrotic cells were analyzed by FACS using FITC-Annexin V and PI. $\square$, Annexin (-) PI (-); $Z$, Annexin (+) PI (-); $₫$, Annexin (-) PI (+); ${ }^{\circ}$, Annexin (+) PI (+). Values are indicated as means $\pm \mathrm{SD}(\mathrm{n}=4) . *, * *$ : Significantly different from the values of the cells incubated under the same conditions without organotin compounds $(\mathrm{p}<0.05$ or 0.01$)$.

to thymus atrophy, TPT or TBT and Dex caused a linear decrease in the weight of the thymus with time (6-24 hr) following administration (Fig. 5). In regard to reduction of thymocyte subpopulations in the thymus as a result of TPT or TBT, there was no significant difference in the percentages of $\mathrm{CD} 4(+) \mathrm{CD} 8(+), \mathrm{CD} 4(+) \mathrm{CD} 8(-), \mathrm{CD} 4(-) \mathrm{CD} 8(+)$ and $\mathrm{CD} 4(-) \mathrm{CD} 8(-)$ thymocytes between the control and organotin-treated groups (data not shown).

Detection of apoptotic cells in thymocytes in vivo: As illustrated in Fig. 6, the flow cytometry analysis also revealed that treatment with TPT or TBT did not increase the number of apoptotic cells at $6 \mathrm{hr}$, as evaluated by the abundance of annexin $\mathrm{V}$ positive thymocytes, although Dex did induce an increase in the number of apoptotic thymocytes in vivo. Moreover, as shown in Fig. 7, typical DNA laddering, a hallmark of apoptosis, was detected only in the thymocytes obtained from Dex-treated mice (lane C), whereas the thymocytes from the TPT- or TBT-treated mice did not show this typical DNA fragmentation (lanes D and E). Histopathological analysis revealed that decreases in cellular density occurred in these thymuses without an increase in necrotic cells (data not shown).

\section{DISCUSSION}

In the present in vivo study, significant transient reductions in peripheral lymphocytes were observed in TPT- or TBT-treated mice (Fig. 1), and analysis of peripheral lymphocyte subpopulations by flow cytometry revealed that the rates of reduction in B-cells for TPT and TBT were significantly higher than those in T-cells (Fig. 2), indicating that Bcells might be more sensitive to the organotins than T-cells in mice. In regard to the lymphocyte subpopulations, previous studies have reported that organotin compounds mainly suppressed T-cell dependent immunofunctions in rats [1, 21] and mice [16]. Although another study showed that DBT decreased in vitro survival, proliferation and differentiation of normal human B lymphocytes [4], the present results demonstrated that B-lymphocytes might also be an important target for induction of immunotoxicity by organotin compounds in mice.

Because it has been suggested that organotin-induced deletion of peripheral lymphocytes is likely a component in the overall risk for immunotoxic responses in exposed humans [24], we attempted to reveal the mechanism of the transient reduction in peripheral lymphocytes induced by TPT and TBT. Although we could detect transient decreases of peripheral lymphocytes in blood from Dex-, TPT- and TBT-treated mice, we could not observe the characteristics of apoptosis or necrosis, such as DNA laddering or staining patterns for annexin $\mathrm{V}$ and PI, in the peripheral lymphocytes isolated from these mice in vivo at any time after administration. On the other hand, we could detect apoptotic cells in the thymuses obtained from the same Dextreated mice. From these results, we concluded that such an in vivo experiment was suitable for observation of the apoptotic or necrotic reactions induced by these chemicals in the thymus, but not in peripheral lymphocytes. Therefore, the 


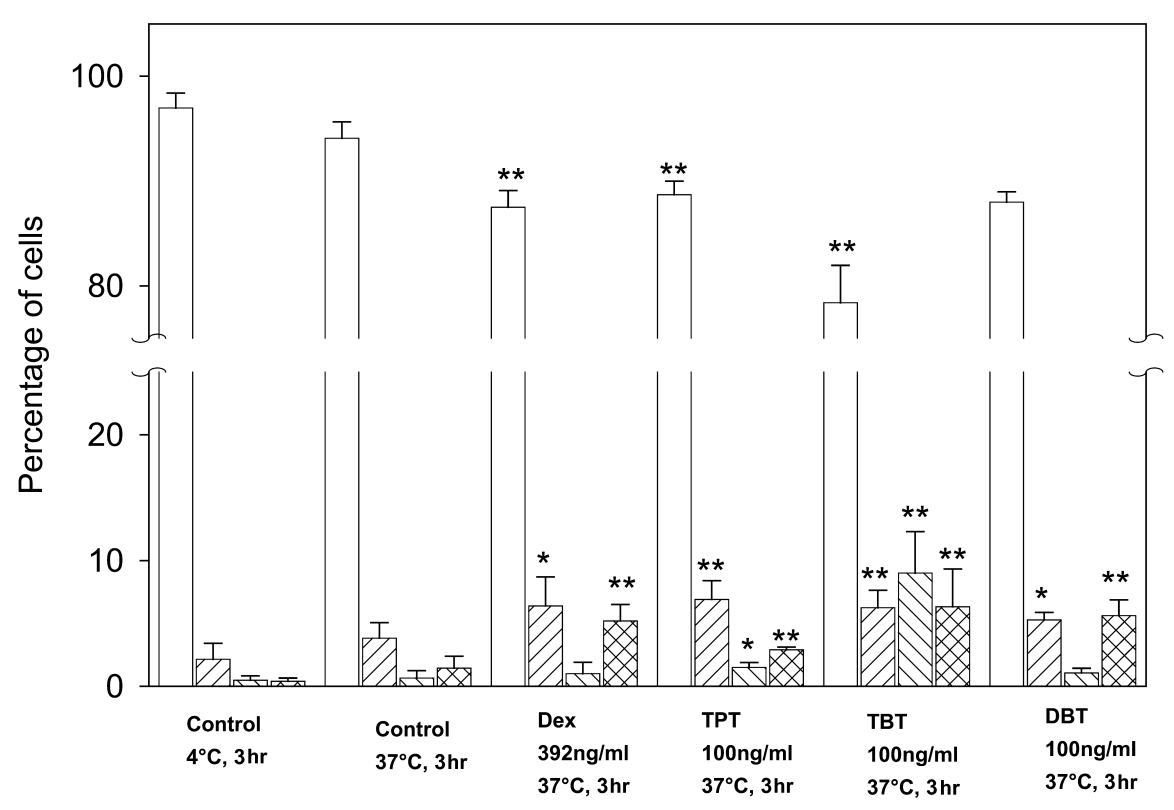

Fig. 4. The effects of organotin treatments on lymphocytes prepared from normal mouse peripheral blood in vitro (2). The lymphocytes were incubated with the organotin compounds (392 $\mathrm{ng} / \mathrm{m} l$ for Dex; $100 \mathrm{ng} / \mathrm{ml}$ for TPT, TBT and DBT) in RPMI- 1640 medium at $37^{\circ} \mathrm{C}$ for $3 \mathrm{hr}$, and then the apoptotic or necrotic cells were analyzed by FACS using FITC-Annexin V and PI. $\square$, Annexin (-) PI (-); $\underset{Z}{ }$, Annexin (+) PI (-); $\mathbb{N}$, Annexin (-) PI (+); ${ }^{2}$, Annexin (+) PI (+). Values are indicated as means $\pm \operatorname{SD}(\mathrm{n}=4) . *{ }^{*}, *$ : Significantly different from the values of the cells incubated under the same conditions without organotin compounds $(\mathrm{p}<0.05$ or 0.01$)$.
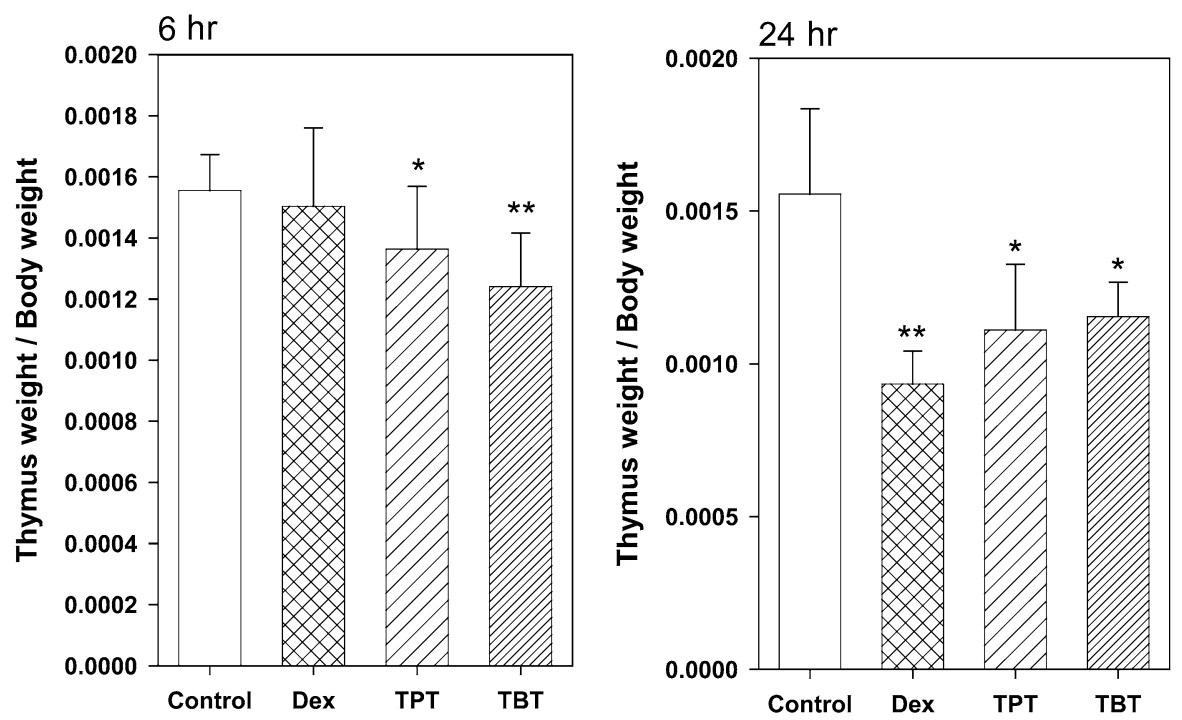

Fig. 5. Thymus atrophy induced by the organotin compounds at 6 and $24 \mathrm{hr}$ after oral administrations in mice. The organotin compounds were administered orally $(180 \mu \mathrm{mol} / \mathrm{kg})$, while dexamethasone $(3 \mathrm{mg} / \mathrm{kg}$ ) was given intraperitoneally, and the ratio of thymus weight to body weight was measured. Values are indicated as means $\pm \mathrm{SD}(\mathrm{n}=4), *, * *$ : Significantly different from the values before administration $(\mathrm{p}<0.05$ or 0.01$)$.

lymphocytes isolated from normal mice were exposed to Dex, TPT or TBT at the concentrations observed in the blood of mice administered these chemicals (Table 1), and then the percentages of apoptotic or necrotic cells were analyzed by flow cytometry. When the isolated lymphocytes were exposed to $500 \mathrm{ng} / \mathrm{m} l$ of TPT, the ratio of necrotic cells 


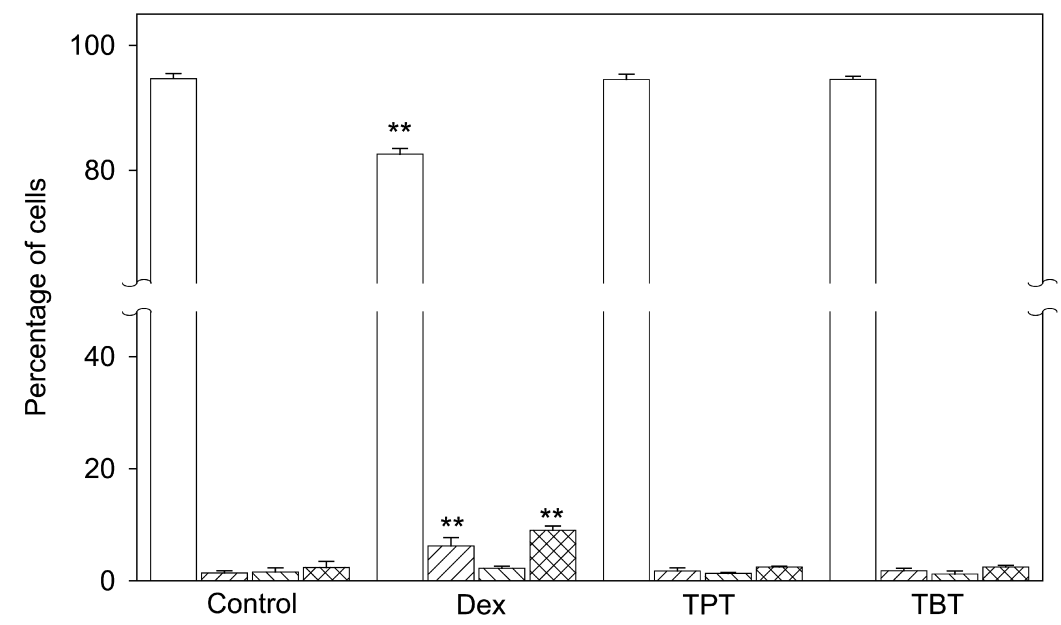

Fig. 6. The effect of organotin on thymocytes isolated from the mouse thymus at $6 \mathrm{hr}$ after the in vivo treatments. The apoptotic or necrotic cells were analyzed by FACS using

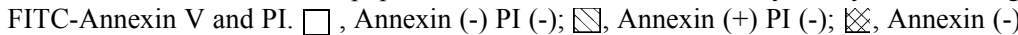
PI $(+)$; $\otimes$, Annexin $(+)$ PI $(+)$. Values are indicated as means \pm SD $(n=4) . *, * *$ : Significantly different from the values of the cells incubated under the same conditions without organotin compounds $(\mathrm{p}<0.05$ or 0.01$)$.

$3 \mathrm{~h}$

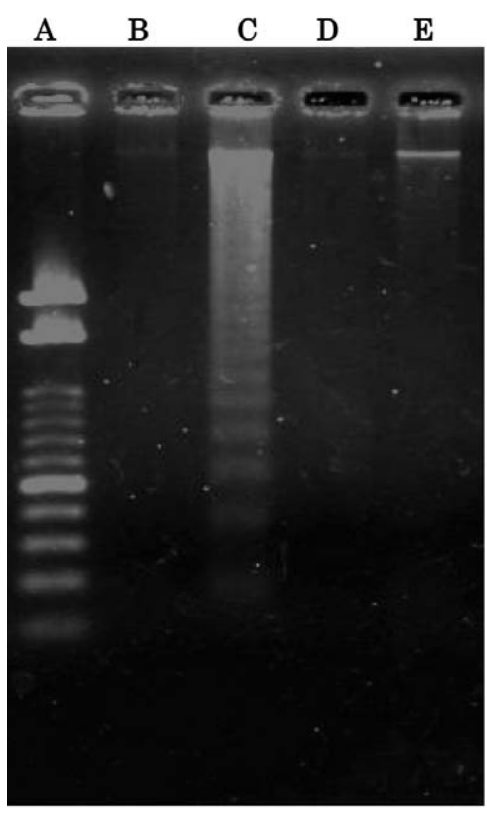

$6 \mathrm{~h}$

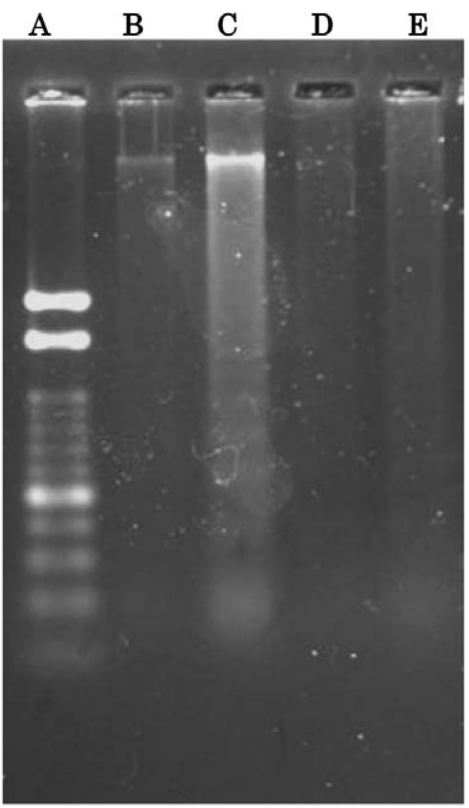

Fig. 7. DNA fragmentation in thymocytes at 3 or $6 \mathrm{hr}$ after administration of dexamethasone $(3 \mathrm{mg} / \mathrm{kg}$, i.p.) or the organotin compounds $(180 \mu \mathrm{mol} / \mathrm{kg}$, p.o.). Lowmolecular-weight DNA was extracted from the cells of mice and electrophoresed on $2.0 \%$ agarose gels, as described in the Materials and Methods. Fragmentation of DNA was detected in the thymocytes of dexamethasone-injected mice (lane C) at 3 and $6 \mathrm{hr}$ after administration, but not in those of the Control (lane B). TPT-treated (lane D) and TBT-treated (lane E) mice. Lane A is a 100 bp DNA ladder marker. One representative experiment of three replicates is shown.

that showed annexin V (-) PI (+) reached about $70 \%$ within $1 \mathrm{hr}$ of exposure (Fig. 3), indicating that the transient reduction in lymphocytes of the TPT-treated mice was attributed to necrosis induced by TPT in vivo. On the other hand, both apoptosis and necrosis were observed in the isolated lymphocytes within $3 \mathrm{hr}$ of exposure to $100 \mathrm{ng} / \mathrm{ml}$ of TBT, and 
DBT exposure at the same concentration could induce only apoptosis in the isolated lymphocytes (Fig. 4), suggesting that the transient reduction of peripheral lymphocytes observed in the TBT-treated mice was attributed to apoptosis as well as necrosis induced by TBT and its metabolite, DBT, in vivo. Thus, DBT, the main metabolite of TBT, might be involved in the transient reduction in peripheral lymphocytes in vivo as well as hepatotoxicity by TBT in mice [28]. However, the participation ratio of apoptosis and necrosis in regard to the transient reduction in peripheral lymphocytes might differ according to the concentrations of organotin and their metabolites in the blood.

Previous studies have suggested the participation of apoptosis in the thymus atrophy caused by organotins $[7,20]$, and the present study showed thymus atrophy at $6 \mathrm{hr}-24 \mathrm{hr}$ after TPT or TBT administration (Fig. 5). Therefore, we examined the induction of apoptosis in thymuses obtained from mice at $3 \mathrm{hr}$ or $6 \mathrm{hr}$ after administration of the organotins or Dex, the positive control, in vivo. As expected, DNA laddering characteristic of apoptosis was observed in the thymocytes obtained from the Dex-treated mice; however, the TPT- or TBT-treated mice did not show such DNA laddering (Fig. 7). Flow cytometric analysis for detection of apoptotic cells showed the same results (Fig. 6). Moreover, histopathological analysis showed decreases in cellular density were observed in these thymuses without an increase in necrotic cells (data not shown). Because the organotin levels in the thymus at $24 \mathrm{hr}$ reached levels that could induce necrosis in vitro $(778 \pm 572 \mathrm{ng}$ TPT/g for TPT-treated mice; $1,452 \pm 159 n \mathrm{~g} \mathrm{TBT} / \mathrm{g}$ for TBT-treated mice), the necrotic cells might be detected after more than $24 \mathrm{hr}$. However, our results indicated that neither apoptosis nor necrosis may largely participate in thymus atrophy within $24 \mathrm{hr}$ after organotin administration. Gennari et al. reported that the main mechanism of thymus atrophy by TBT at a lower dosage $(55 \mu \mathrm{mol} / \mathrm{kg})$ might be antiproliferative effects by DBT metabolized from TBT [6]. Therefore, we concluded that inhibition of thymocyte proliferation may be the main mechanism of the thymus atrophy induced by TPT or TBT even at such a high dosage.

In conclusion, our results demonstrated that apoptosis, which is one of the most interesting toxicological mechanisms of organotin compounds, may not be involved in the thymus atrophy induced by TPT and TBT in mice, and the cause of this phenomenon may be the antiproliferative effects on thymocytes of these organotin compounds. On the other hand, the transient reduction of peripheral lymphocytes observed in the TPT-treated mice might be induced by a direct necrotic reaction by TPT. In the case of TBTtreated mice, apoptosis might participate in the reduction of peripheral lymphocytes as well as necrosis induced by TBT. Thus, the thymus atrophy and transient reduction of peripheral lymphocytes by the organotin compounds in vivo were caused by different mechanisms.

ACKNOWLEDGMENT. This study was supported in part by a Grant from the School of Veterinary Medicine and Ani- mal Sciences, Kitasato University.

\section{REFERENCES}

1. Attahiru, U. S., Iyaniwura, T. T., Adaudi, A. O. and Bonire, J. J. 1991. Subchronic toxicity studies of tri-n-butyltin and triphenyltin acetates in rats. Vet. Hum. Toxicol. 33: 499-502.

2. Aw, T. Y., Nicotera, P., Manzo, L. and Orrenius, S. 1990. Tributyltin stimulates apoptosis in rat thymocytes. Arch. Biochem. Biophys. 283: 46-50.

3. Boyer, I. J. 1989. Toxicity of dibutyltin, tributyltin and other organotin compounds to humans and to experimental animals. Toxicology 55: 253-298.

4. De Santiago, A. and Aguilar-Santelises, M. 1999. Organotin compounds decrease in vitro survival, proliferation and differentiation of normal human B lymphocytes. Hum. Exp. Toxicol. 10: 619-624.

5. Gennari, A., Bol, M., Seinen, W., Penninks, A. and Pieters, R. 2002. Organotin-induced apoptosis occurs in small $\mathrm{CD} 4(+) \mathrm{CD} 8(+)$ thymocytes and is accompanied by an increase in RNA synthesis. Toxicology 175: 191-200.

6. Gennari, A., Potters, M., Seinen, W. and Pieters, R. 1997. Organotin-induced apoptosis as observed in vitro is not relevant for induction of thymus atrophy at antiproliferative doses. Toxicol. Appl. Pharmacol. 147: 259-266.

7. Gennari, A., Viviani, B., Galli, C. L., Marinovich, M., Pieters, R. and Corsini, E. 2000. Organotins induce apoptosis by disturbance of $\left[\mathrm{Ca}^{2+}\right]$ (i) and mitochondrial activity,causing oxidative stress and activation of caspase in rat thymocytes. Toxicol. Appl. Pharmacol. 169:185-190.

8. Grote, K., Stahlschmidt, B., Talsness, C. E., Gericke, C., Appel, K. E. and Chahoud, I. 2004. Effects of organotin compounds on pubertal male rats. Toxicology 202: 145-158.

9. Harrison, P. T., Holmes, P. and Humfrey, C. D. 1997. Reproductive health in humans and wildlife: are adverse trends associated with environmental chemical exposure? Sci. Total. Environ. 205: 97-106.

10. Hoch, M. 2001. Organotin compounds in the environment - an overview. Appl. Geochem. 16: 719-743.

11. Kannan, K., Tanabe, S. and Tatsukawa, R. 1995. Occurrence of butyltin residues in certain foodstuffs. Bull. Environ. Contam. Toxicol. 55: 510-516.

12. Kannan, K., Guruge, K. S., Thomas, N. J., Tanabe, S. and Giesy, J. P. 1998. Butyltin Residues in Southern Sea Otters (Enhydra lutris nereis) Found Dead along California Coastal Waters. Environ. Sci. Technol. 32:1169-1175.

13. Kannan, K., Grove, R. A., Senthilkumar, K., Henny, C. J. amd Giesy, J. P. 1999. Butyltin compounds in river otters (Lutra canadensis) from the northwestern United States. Arch. Environ. Contam. Toxicol. 36: 462-468.

14. Kashimoto, T., Ueno, S., Hayashi, H., Hanajima, M., Yoshioka, K., Yoshida, K., Mutoh, K. and Susa, N. 2005. Depletion of lymphocytes, but not neutrophils, via apoptosis in a murine model of Vibrio vulnificus infection. J. Med. Micro. 54: $15-22$.

15. Lee, J. J., Kim, Y. M., Park, S. K. and Lee, M. K. 2006. Effects of tributyltin chloride on L-DOPA-induced cytotoxicity in PC12 cells. Arch. Pharm. Res. 29: 645-650.

16. Nishida, H., Matsui, H., Sugiura, H., Kitagaki, K., Fuchigami, M., Inagaki, N., Nagai, H. and Koda, A. 1990. The immunotoxicity of triphenyltin chloride in mice. J. Pharmacobiodyn. 13: $543-548$.

17. Nakatsu, Y., Kotake, Y., Komasaka, K., Hakozaki, H., Tagu- 
chi, R., Kume, T., Akaike, A. and Ohta, S. 2006. Glutamate excitotoxicity is involved in cell death caused by tributyltin in cultured rat cortical neurons. Toxicol. Sci. 89: 235-242.

18. Penninks, A. H. 1993. The evaluation of data-derived safety facters for bis(tri-n-butylrin)oxide. Food. Addit. Contam. 10: 351-361.

19. Pieters, R. H., Bol, M., Lam, B. W., Seinen, W. and Penninks, A. H. 1992. The organotin-induced thymus atrophy, characterized by depletion of CD4+ CD8+ thymocytes, is preceded by a reduction of the immature CD4- CD8+ TcR alpha beta-/low CD2high thymoblast subset. Immunology 76: 203-208.

20. Raffray, M. and Cohen, G. M. 1993. Thymocyte apoptosis as a mechanism for tributyltin-induced thymic atrophy in vivo. Arch. Toxicol. 67: 231-236.

21. Smiaowicz, R. J., Riddle, M. M., Rogers, R. R., Leubke, R. W., Copeland, C. B. and Ernst, G. G 1990. Immunealterations in rats following subacute exposure to tributyltin oxide. Toxicology 64: 169-178.

22. Snoeij, N. J., van Iersel, A. A., Penninks, A. H. and Seinen, W. 1985. Toxicity of triorganotin compounds: comparative in vivo studies with a series of trialkyltin compounds and triphenyltin chloride in male rats. Toxicol. Appl. Pharmacol. 81: 274-286.

23. Snoeij, N. J., Penninks, A. H. and Seinen, W. 1988. Dibutyltin and tributyltin compounds induce thymus atrophy in rats due to a selective action on thymic lymphoblasts. Int. J. Immunopharmacol. 10: 891-899.

24. Stridh, H., Cotgreave, I., Müller, M., Orrenius, S. and Gigliotti, D. 2001. Organotin-induced caspase activation and apoptosis in human peripheral blood lymphocytes. Chem. Res. Toxicol. 14: 791-798.

25. Suzuki, T. 2003. Environmental chemistry of organotin compounds. J. Food Hyg. Soc. Jpn. 44: 269-280.

26. Suzuki, T., Matsuda, R., Saito, Y. and Yamada, H. 1994. Application of helium microwave-induced plasma emission detection system to analysis of organotin compounds in biological samples. J. Agric. Food Chem. 42: 216-220.

27. Szondy, Z., Reichert, U., Bernardon, J. M., Michel, S., Toth, R., Karaszi, E. and Fesus, L. 1998. Inhibition of activationinduced apoptosis of thymocytes by all-trans- and 9-cis-retinoic acid is mediated via retinoic acid receptor alpha. Biochem. J. 331: 767-774.

28. Ueno, S., Susa, N., Furukawa, Y. and Sugiyama, M. 1994. Comparison of hepatotoxicity caused by mono-, di- and tributyltin compounds in mice. Arch. Toxicol. 69: 30-34.

29. Vos, J. G., van Logten, M. J., Kreeftenberg, J. G. and Kruizinga, W. 1984. Effect of triphenyltin hydroxide on the immune system of the rat. Toxicology 29: 325-336. 